\title{
Passing of Mucus Plug
}

National Cancer Institute

\section{Source}

National Cancer Institute. Passing of Mucus Plug. NCI Thesaurus. Code C92840.

A discharge of the mucus plug from the cervical os during cervical dilation in preparation

for the labor and delivery of the baby. 